Volume 8. No. 1.1, 2020

International Journal of Emerging Trends in Engineering Research

Available Online at http://www.warse.org/IJETER/static/pdf/file/ijeter0581.12020.pdf

https://doi.org/10.30534/ijeter/2020/0581.12020

\title{
Strategy to Develop Centre of Accreditation of Excellence (CARE) with Industrial-based Recognition
}

\author{
A.W. Muhd Akhir,4, S. Sarip ${ }^{2}$ and A.Y. Abd Fatah ${ }^{3}$ \\ ${ }^{1}$ Universiti Teknologi Malaysia, Kuala Lumpur, Malaysia, asymal@mara.gov.my \\ ${ }^{2}$ Universiti Teknologi Malaysia, Kuala Lumpur, Malaysia, shamsuls.kl@utm.my \\ ${ }^{3}$ Universiti Teknologi Malaysia, Kuala Lumpur, Malaysia, yasser.kl@utm.my \\ ${ }^{4}$ Majlis Amanah Rakyat, Kuala Lumpur, Malaysia, asymal@mara.gov.my
}

\begin{abstract}
This paper presents the strategy to develop Centre of Accreditation and Recognition of Excellence (CARE) with Industrial-based Recognition. The issue of unemployed graduates or graduates failing to obtain a job equivalent to their qualifications is a subject often addressed today by the youth. Employers argue that many graduates do not have the knowledge, skills and abilities relevant to the requirements of the industry, even though they have spent three to five years pursuing a diploma or bachelor's degree. The aim of this study is to review the strategy in developing Centre of Accreditation and Recognition of Excellence (CARE) with Industrial-based Recognition. In this study, the strategic factors of previous case studies were identified. These strategic factors will then be verified by TVET and industry experts using the Delphi method. After the evaluation process, some of the strategic factors were ignored and new factors were included. In the end, the authorized body certification and skill sets are the new findings by expert group for the strategy in developing Centre of Accreditation and Recognition of Excellence (CARE) with Industrial-based Recognition.
\end{abstract}

Key words : CARE, TVET, Delphi method, authorized body certification, skill sets

\section{INTRODUCTION}

In recent years, the number of new graduates or graduates of local and foreign higher learning institutions who are still unemployed has increased. The slow pace of economic growth, unpredictable changes in the industrial demands and graduates not meeting the industrial needs are among the factors contributing. The main reason given from the industry for this phenomenon is inadequate technical skills from the fresh graduates, which were lower than the industrial requirements.
In addition, industry players are looking for fresh recruits with critical thinking skills and knowledge depth that comes from knowing not just how to execute a given task, but the logic behind it. However, employers around the country typically believed there were insufficient skill among the graduates, indicating that the universities do not actually have ample incentives for students to acquire the labor market-critical skills [1]. Technical Education and Vocational Training (TEVT) is a part of the Higher Education (HE) system implementer in Malaysia. The standard of service delivered is essential to the growth of the nation as it trains skilled human resources that can function for the future [1].

Accreditation is a process in which certification of competency, authority, or credibility is presented. The accreditation process ensures that the certification procedures are reasonable; usually meaning they are qualified to check and approve third parties, behaving in an ethical manner and employing adequate quality assurance (QA). In Malaysia, accreditation is a formal recognition that a certificate, diploma or degree program has attained the quality standards and criteria set by Malaysian QA. In terms of accreditation, Malaysian education system has had two accreditation bodies: the Department of Skills Development (DSD), which accredits the skills sector and the Malaysian Qualifications Agency (MQA), a division within the Ministry of Education that accredits the vocational, technical and academic sectors.

MQA accreditation is a qualification resulting from MQA's quality evaluation. It is MQA's pledge to all higher education stakeholders (i.e. students, parents, employers) that the quality of an MQA-accredited program is assured accordingly. In doing so, it is recognizing the system for a number of purposes which is often a foundation for certain parties. For example, this accreditation status would be used by the Public Service Department (PSD) to identify the qualification for public service jobs. 
An accredited centre by DSD usually means an organization or place of work approved by DSD. It provides the Malaysian Skills Certification applicants for participation and training in areas in unique area based on the standards from National Occupational Skills Standard (NOSS) with expertise level from Malaysian Skills Certificate or SKM to Malaysian Skills Advanced Diploma or DLKM.

As an initiative under the 11th Malaysia plan, a Single Quality Assurance Framework for TVET is proposed, aimed at enhancing the quality of TVET students, increasing the standard of TVET and, ultimately, mainstreaming TVET pathways comparable to academic pathways, in order to meet the job needs of the Malaysian industries. The MQA from Ministry of Education and the DSD from Ministry of Human Resources are working together to run this program in an integrated way. To be more robust and reliable, the initiative aimed to improve the accreditation framework for TVET programs.

The initiative to harmonize and unify different QA systems into a single QA framework started with the Malaysian Qualifications Framework (MQF) reform, in which the skills sector and the vocational and technical sector were integrated into the TVET sector. The TVET Program Accreditation Code of Practice (COPTPA) had been outlined in order to operationalize the single QA system of the TVET program. Consequently, COPTPA has been used as the main reference for TVET accreditation. The scope of TVET Standards in COPTPA covers qualifications from Level 1 to Level 5 of the MQF [2].

\section{OVERVIEW OF OTHER TVET PROGRAMS}

\subsection{TVET Quality Assurance Strategies in Different Countries}

The accreditation promotion experience of advanced countries needed to be learned. Taiwan has an extensive experience about their TVET program. The Board of Accreditation of Non-Formal Learning Programs in Taiwan was formed to establish processes in order to facilitate the accreditation of accomplishments of non-formal study. As described, the approaches used by Taiwan accreditation organizations differ, and there is a lack of collaboration and cooperation between those agencies. Thus, a framework has to be implemented in relevant programs to promote relationship building. By providing financial subsidies, stakeholder opportunities and flexible accreditation processes, the partnership between different accreditation partners can be strengthened and effective communication channels can be developed, thereby creating an integrated learning accreditation program that benefits lifelong learners [3].
Indonesia saw labor as a human resource to play an important role in the growth of the country and their education system needed improvement to deliver good human resources. If this were to be realized, unemployment rate in Indonesia will be reduced. Active and skilled vocational education is the training that can encourage students with real experience, equipment, devices, materials, and working methods. This is in line with what was started by Hasan Ali Yildirim and Simsek [4] where according to them, vocational education is deemed effective as long as it meets the students and industrial needs. Hence, students need a high-quality education to reach the ability standards needed by the workplace.

From TVET, industry requires their potential employees to undergo specialized training in priority skills. Therefore, the idea of Holistic Skills Education (HOLSKED) needed to be actualized. HOLSKED is an improvement of QA management principle that is intended to provide students with an effective learning experience. The implementation of the management model is suggested to be optimal and it is based on the HOLSKED phases. This model is proven successful especially in developing the attitude and self-reliance that can resolve the problems and raise knowledge of specific skills among students [5].

Currently, schools need dramatic reform. Now is the time in a society in which conventional teaching is dominated by evidence-based knowledge. Yet life needs people to do more than they need to learn, so that we can work [6]. Throughout the past decades, educational scholars and politicians have shown growing interests in the idea of functional learning, i.e., workplace learning. Practical learning plays a significant role in lifelong learning, because the workplace is an obvious environment for achieving this objective [7]. Disseminating new methods of providing in-house skills upgrade processes that substantially reduced the costs of expertise and knowledge transfer, improving development capabilities, and expertise transfer to TVET schools through the use of Student Response Systems technologies [8].

Educational disadvantage leads many fresh graduates to become disadvantaged in terms of jobs and other opportunities for living. It is hoped that Vocational education and training (VET) will provide skills to mitigate this situation. Findings of an exploratory study conducted on four VET programs for disadvantaged youth in rural areas of the district of Mbarara, southwestern Uganda, were obtained after investigating existing VET practices and how young people are prepared for the labor market and prospects for living. The results suggest that VET can improve labor market access and livelihood opportunities, but there are ranges of areas that need improvement. More learning-by-doing, interactive learning and industrial training should be incorporated into the current pedagogy in order to enrich the 
experiences of the learners so that they can match up to the tasks provided in the labor market later on [9].

By 2020, Vietnam aims to shift towards a nation that is radically industrialized and modernized, and one of the keys is to build human capital based on high-quality vocational training. Thus, in this strategy, Vietnam State Government introduced a set of steps, relating to QA such as linking vocational training with labor markets and increasing enterprise involvement in the TVET sector. Some practical steps have been found to increase the labor market value of TVET qualification such as enterprises should be more active in vocational training activities: establishing vocational skills requirements, defining work categories, designing curriculum, and evaluating the learning outcomes of vocational learners [10].

Cooperation between different educational institutions, the local government and the employers is essential in Latvia. Effective relationships between all stakeholders and consistency of all processes are important, and hence the QA needs to be harmonized within the integrated VET and HE framework and used jointly by all concerned partners. Together with municipalities and educational institutions in the particular community or country, entrepreneurs are key players in the preparation of future skilled specialists for the particular community, especially in the context of globalization and technological growth. Cooperation between the VET and Higher Education (HE) is still a much overlooked feature. Employers should therefore invest not only in school education but also in the acquisition of a common language with other stakeholders. With resources already implemented in HE, quality and accountability in VET could be increased. Mentoring is an effective way to develop VET and HE in an integrated way in the local context, and mentors should take due consideration of these common language instruments [11].

One of the key types of VET in Russia is advanced vocational education; hence, the quality models of VET were analyzed using the example of advanced vocational training. Until 2011, the external VET quality assessment in Russia was performed based on state accreditation standards and included a self-assessment once in every five years. Russia has been conducting research on VET quality growth and the possibilities of adopting the latest European standard on the QA framework for VET Quality in Russia. The QA system assigns considerable importance to employers and their participation in making decisions about the curriculum material. Sometimes, they do not need the formal accreditation of educational institutions, they pay great attention to the VET organization's reputation, and they trust the partners they have checked out [12].
As a country with a young population, Kosovo has experienced sustained economic growth since its independence in 2008; however, it remains one of the Europe's poorest nations. While responsibility for such a situation can be divided into several dimensions, the findings of this research work have indicated that VET is the right address to look for solutions to the issue. VET institutions in Kosovo are actively working to prepare applicants for the labor market by equipping them with the appropriate skills and considering the QA process as their primary responsibility. The accreditation and quality enhancement processes in Kosovo's VET institutions are challenges for the time they live in, despite their technical qualifications and importance to the labor market, which is closely linked to the development of individual knowledge and skills and their jobs. Professional standards should be established explicitly based on the workplace-assigned occupation requirements. The employer therefore takes an active part in the process and sets the necessary conditions that the worker must met in order to apply. Accreditation of VET programs, they concluded, has a positive effect on the job market, which is only open to applicants trained by accredited programs. It should be remembered that the labor markets in Kosovo as of today are moving faster than ever [13].

In Romania, the QA Law No. 87/2006 formed a legal institutional structure for the establishment and implementation of QA frameworks at program and provider level in the field of education. The law lays out a number of fundamental concepts that extend to both pre-university (including Initial Vocational Education Training such as school- and work-based VET programmes and post-secondary programmes) and HE levels: concentrating on learning outcomes, encouraging continuous development, protecting educational recipients (first of all students) and giving priority to provider's internal evaluation (self-assessment). The Romanian Agency for QA was established and is responsible for the authorization, accreditation and external assessment of all providers of education and training [14].

In terms of having an understanding of VET QA in Germany, three overarching concepts are being important; the dual principle, the occupation principle and the principle of consensus:

a.) The dual theory blends work-life learning with vocational school learning and, at the same time, encourages the development of professional experience.

b.) The principle of occupation is based on a certification that is binding and recognized throughout the world. It offers the ability to exercise a multitude of job activities.

c.) The principle of consensus ensures proximity to the labor market, openness and acceptance of vocational training through the participation of the social partners, the Federal 
Government and the federal states in the establishment of national training requirements.

Important QA instruments in VET of Germany are outlined as follows: national standards based on VET law, tracking of initial and ongoing VET learning, and finally comparing the German Qualification Framework (DQR) to the European Qualifications Framework (EQF), allowing for more clarity and qualification comparability within the EU. The approaches to QA are based on quality frameworks, educational standards, centralized examinations, monitoring and benchmarking exercises, as well as school inspection. In some cases, such as the Baden-Württemberg Landesinstitut für Schulentwicklung, specialized quality development agencies are responsible for overseeing vocational schools. As company-based VET is a core part of the German dual framework, employers are essential QA partners in the initial VET process. The Federal Association of German Employer Associations (BDA) plays a key role in VET policy, including the implementation of training legislation and the establishment of minimum requirements for initial VET dependent on businesses. Local chambers of industry and commerce and chambers of art and trade typically monitor the regulations on training facilities and trainers. They have a panel in German to discuss the return on education, the development of lifelong learning skills and the transition from VET to the labor market [15].

\subsection{Implementation of Strategy on Work-based Learning (WBL)}

In Romania, WBL is integrated as a cross-sectional issue into a national legislation. It is concluded that there are no clear legal requirements for companies to engage in WBL initiatives in Romania. All companies can conclude apprenticeship contracts if they have the required facilities and provide local labor with proof that they have a particular apprenticeship-training program for which they wish to organize apprenticeships. The work-based apprenticeship program is designed only for certain skills, for which job requirements or technical training criteria and occupations are included in the Romanian Occupational Classification. The minimum length of the apprenticeship training is equaled to the time specified by the training regulations for adult training certificates. The required time for the theoretical training is included in the daily work hours. The practical aspect of vocational training may be undertaken either as a work-based learning or as on-the-job training [16]. Under existing law, practical classes can be conducted with employers on the principles of the dual education program, based on two forms of contracts: a vocational training contract concluded between the graduate and the employer; or an apprenticeship contract concluded between the school principal and the apprenticeship host employer of the students [17].
In Germany, the dual training program seemed as an effective model for structuring the transition from school to working life. The apprenticeship is followed by a final exam, which the chambers administered. All companies involved in the vocational training system are supervised by the different chambers representing the field of operation of the companies or the responsible national administrative authority.

There is no clear law in Portugal governing WBL on a single-handed basis. As part of other legislation, it is regulated as a cross-sectional subject [18]. However, it should be noted that for the VET-dual education programs, it is typically up to the VET provider to develop a partnership with companies that host learners during WBL. The VET providers need to retain the certification and are therefore audited regularly. Through the audit, the criteria used to select the companies and the pedagogical approaches that include frameworks for monitoring and evaluating the activities of the WBL are examined. Nevertheless, there was no suggestion that the businesses participating in WBL projects are subject to more regular audits by labor supervisory bodies. There was no specific labor legislation governing apprenticeship programs, internships, and other WBL programs. General guidelines for WBL programs are that a contract must always be signed by all the parties concerned, where it should be understood that the students are entitled to meal and travel vouchers, and the company's job insurance.

The dual education is governed in Bulgaria as part of VET by the same institutions that are responsible for VET. WBL is mandatory in any VET program but is not considered a separate legal study form. There are numerous agencies responsible at all levels-state, regional and local [19]. Companies wishing to engage in WBL programs in partnership with VET schools require the General Labor Inspectorate Executive Agency's special permission to hire people below the age of 18. The permit is granted after the General Labor Inspectorate Executive Agency inspects the work facilities and only grants permit if the work atmosphere is found to meet all Occupational Safety and Health requirements. There is no unique law that covers schooling, internships and other WBL programs. Employer-student partnerships are formalized in a contract that will be compliant with the Labor Code. A basic condition for dual training is the completion of the work contract no later than two weeks before the beginning of the school year in which the training will begin. There is no clear public registry in Bulgaria where companies taking part in dual training are signed

No relevant legislation in the WBL sector exists in Cyprus. The Council of Ministers or the law enacted by the House of Representatives legalizes all practices related to the provision 
of continuing VET. Each company in Cyprus has the right to participate in WBL training programs, without any limitations on membership, type of business or type of training. Many employers have the capacity to coordinate and enforce any training they considered to contribute to the growth of their workforce at their own expense [20]. When the training is a business project and is solely coordinated and enforced by the business, then there is no external auditing of the specified audits that are or will be carried out in this company. If an organization participated in vocational training programs through the Cyprus Human Resource Development Authority and collaborates with VETs, then they are responsible for the quality control in implementing the adopted programs [21].

The duality of the vocational training can be characterized as a combination of learning in the company and learning in the vocational training institution or training center where the company focuses on providing practical knowledge while the vocational school / training center offers the theoretical dimension of knowledge for trainees or learners. This duality of VET is very crucial for the sustainability of Malaysia in terms of economic and social security. The government of Malaysia has agreed to introduce National Dual Training System (NDTS), recognizing the value of providing a more formal and comprehensive skills training programs. This is because the comprehensive and well-developed skills training program is vital for ensuring the country's competitiveness. The NDTS is an apprenticeship training scheme modelled on the German dual framework where training is undertaken in both industry and technical institutes.

Employer is one of the NDTS programs most significant stakeholders and their job is to provide and help DSD with appropriate feedback from their needs and expectations in terms of employee awareness, competence and expertise. Apart from that, employers must also actively participate in NDTS by providing training to apprentices in the context of Learn and Work Assignments (LWA), mixed approaches and four steps, as outlined in the National Occupational Core Curriculum (NOCC). Industry assistance in the implementation of the NDTS is therefore very crucial [22].

The essence of the NDTS is practical training provided by industries in a real environment to deal with the day-to-day problems of the industry. The technology used in industry can only be effectively educated in an industrial setting while the academic institutions have the theoretical aspects thereof. Industry preparation is therefore the highest priority at NDTS. This is why formal and theory-based expertise can help us better understands the functional aspect of organizational learning [23].

\subsection{Delphi Method}

This study uses the qualitative analysis process to assess the strategy to develop Centre of Accreditation and Recognition of Excellence (CARE) with Industrial-based Recognition. This Delphi technique employs a panel of experts from industry and TVET to determine the strategy to develop Centre of Accreditation and Recognition of Excellence (CARE) with Industrial-based Recognition [24]. The first process is to identify the strategy to develop CARE with Industrial-based Recognition. The Delphi process traditionally starts with an open questionnaire in the first round [25]. Positive brainstorming by the expert panel is achieved in the first round. These strategic factors could be defined as variables. Those variables are identified through a survey process aimed at industry experts and TVET to support the initial literature review information as a Table 1.

Each Delphi participant receives a second questionnaire in the second round and is asked to examine the items summarized by the investigators based on the information provided in the first round. After that discussion, the scale of the discussion will be narrowed. The raking setting will be done through the calculation process once confirmation is done. This ranking process can help researchers conclude on which variables are more important to identify. Information obtained after going through the first to last process will determine the strategy to develop CARE with Industrial-based Recognition.

The questionnaire was distributed to 18 industry and TVET expert panels as shown in Table 2. Nine(9) are from the industry and nine (9) are from the TVET group. The size of the group depends on the group dynamics to reach consensus among professionals and not on the statistical power. The literature recommends 10 to 18 experts on a Delphi panel [26]. In the first round 12 variables are identified as shown in Table 2.

Table 2: First Round: Identification of Variable

\begin{tabular}{|l|l|c|}
\hline No. & \multicolumn{1}{|c|}{ Variable } & Indicator \\
\hline 1 & Quality Assurance & V1 \\
\hline 2 & Financial Subsidies & V2 \\
\hline 3 & Stakeholder Opportunities & V3 \\
\hline 4 & High-Quality Education & V4 \\
\hline 5 & Evidence-Based Knowledge & V5 \\
\hline 6 & Industrial Training & V6 \\
\hline 7 & Industry Involvement & V7 \\
\hline 8 & Work-Based Apprenticeship & V8 \\
\hline 9 & Dual Education & V9 \\
\hline 10 & Dual Training & V10 \\
\hline 11 & Authorized Body Certification & V11 \\
\hline 12 & Skill Sets & V12 \\
\hline
\end{tabular}


A.W. Muhd Akhir et al., International Journal of Emerging Trends in Engineering Research, 8(1.1), 2020, 27 - 35

The second round in Table 3 is a validation phase after the strategic variables have been established. In this second round, it only includes a group of experts. There are five of the industry groups, and the other five are from the TVET group. Results from the second round of this variable have been selected.

Table 3: Second Round: Variable Validation Process

\begin{tabular}{|c|l|c|}
\hline No. & \multicolumn{1}{|c|}{ Variable } & Indicator \\
\hline 1 & Quality Assurance & V1 \\
\hline 2 & High-Quality Education & V4 \\
\hline 3 & Evidence-Based Knowledge & V5 \\
\hline 4 & Industrial Training & V6 \\
\hline 5 & Industry Involvement & V7 \\
\hline 6 & Authorized Body Certification & V11 \\
\hline 7 & Skill Sets & V12 \\
\hline
\end{tabular}

Table 4, reassesses the seven variables by presenting the same 10 experts from round two with points 1 to 10 . All experts shall rate these seven variables by a maximum out of 10 . 
Table 1: First Round: Strategy to develop Centre of Accreditation and Recognition of excellence (CARE) with Industrial-based Recognition

\begin{tabular}{|c|c|c|c|c|c|c|c|c|c|c|}
\hline Author & $\begin{array}{c}\text { Quality } \\
\text { Assurance }\end{array}$ & $\begin{array}{l}\text { Financial } \\
\text { Subsidies }\end{array}$ & $\begin{array}{l}\text { Stakeholder } \\
\text { Opportunities }\end{array}$ & $\begin{array}{l}\text { High-Quality } \\
\text { Education }\end{array}$ & $\begin{array}{c}\text { Evidence- } \\
\text { Based } \\
\text { Knowledge }\end{array}$ & $\begin{array}{l}\text { Industrial } \\
\text { Training }\end{array}$ & $\begin{array}{c}\text { Industry } \\
\text { Involvement }\end{array}$ & $\begin{array}{c}\text { Work-Based } \\
\text { Apprenticeship }\end{array}$ & $\begin{array}{c}\text { Dual } \\
\text { Education }\end{array}$ & $\begin{array}{c}\text { Dual } \\
\text { Training }\end{array}$ \\
\hline C. Te-Yung & $\mathbf{X}$ & $\mathbf{X}$ & $\mathbf{X}$ & & $\mathbf{X}$ & & & & & \\
\hline $\begin{array}{l}\text { H. Simsek and A. } \\
\text { Yildirim }\end{array}$ & & & & $\mathbf{X}$ & $\mathbf{X}$ & & & & & \\
\hline E. Munastiwi & $\mathbf{X}$ & & & & $\mathbf{X}$ & & & & & \\
\hline C. M. Reigeluth & & & & & $\mathbf{X}$ & & & & & \\
\hline V. Aarkrog & & & & & $\mathbf{X}$ & & & & & \\
\hline L. Moldovan & & & & & $\mathbf{X}$ & & & & & \\
\hline C. Tukundane & & & & $\mathbf{X}$ & $\mathbf{X}$ & $\mathbf{X}$ & & & & \\
\hline P. C. Diep & $\mathbf{X}$ & & & $\mathbf{X}$ & $\mathbf{X}$ & & $\mathbf{X}$ & & & \\
\hline I. Buliginaa & $\mathbf{X}$ & & & & $\mathbf{X}$ & & $\mathbf{X}$ & & & \\
\hline G. V. Mozhaeva & $\mathbf{X}$ & & & & $\mathbf{X}$ & & & & & \\
\hline $\begin{array}{l}\text { Z. Halili and A. } \\
\text { Rukovci }\end{array}$ & $\mathbf{X}$ & & & & $\mathbf{X}$ & & $\mathbf{X}$ & & & \\
\hline E. Cerkez & $\mathbf{X}$ & & & & $\mathbf{X}$ & & & $\mathbf{X}$ & & \\
\hline $\begin{array}{c}\text { U. } \\
\text { Hippach-Schneider } \\
\text { and A. Huismann }\end{array}$ & $\mathbf{X}$ & & & & $\mathbf{X}$ & & $\mathbf{X}$ & $\mathbf{X}$ & & $\mathbf{X}$ \\
\hline P. E. Unit & & & & & & $\mathbf{X}$ & $\mathbf{X}$ & & & \\
\hline $\begin{array}{l}\text { E. C. f. t. D. o. V. } \\
\text { Training } \\
\end{array}$ & & & & & $\mathbf{X}$ & & & $\mathbf{X}$ & $\mathbf{X}$ & \\
\hline DGERT & & & & & & $\mathbf{X}$ & & & & $\mathbf{X}$ \\
\hline Cedefop & & & & & & & $\mathbf{X}$ & & $\mathbf{X}$ & $\mathbf{X}$ \\
\hline D. EAC & & & & & & $\mathbf{X}$ & $\mathbf{X}$ & & & \\
\hline $\begin{array}{c}\text { Y. Korelli and Y. } \\
\text { Mourouzides }\end{array}$ & & & & & & & $\mathbf{X}$ & & & \\
\hline J. A. Baser & & & & & & & & & & $\mathbf{X}$ \\
\hline A. Ahmad & & & & & & & & & & $\mathbf{X}$ \\
\hline
\end{tabular}


A.W. Muhd Akhir et al., International Journal of Emerging Trends in Engineering Research, 8(1.1), 2020, 27 - 35

Table 4: Third Round: Data Verification Process (Result)

\begin{tabular}{|c|c|c|c|c|c|c|c|c|}
\hline Experts & V1 & V4 & V5 & V6 & v7 & V11 & V12 & Total \\
\hline & 8 & 8.5 & 7 & 9 & 8.5 & 9 & 9 & 59 \\
\hline & 0.136 & 0.144 & 0.119 & 0.153 & 0.144 & 0.153 & 0.153 & 1 \\
\hline & 8 & 8 & 8.5 & 8 & 7.5 & 8.5 & 8.5 & 57 \\
\hline & 0.140 & 0.140 & 0.149 & 0.140 & 0.132 & 0.149 & 0.149 & 1 \\
\hline & 8.5 & 7.5 & 8 & 7.5 & 8 & 8.5 & 9 & 57 \\
\hline & 0.149 & 0.132 & 0.140 & 0.132 & 0.140 & 0.149 & 0.158 & 1 \\
\hline & 8 & 8 & 8 & 8.5 & 7.5 & 8 & 7.5 & 55.5 \\
\hline & 0.144 & 0.144 & 0.144 & 0.153 & 0.135 & 0.144 & 0.135 & 1 \\
\hline & 7.5 & 8 & 8.5 & 7.5 & 8 & 8 & 8.5 & 56 \\
\hline & 0.134 & 0.143 & 0.152 & 0.134 & 0.143 & 0.143 & 0.152 & 1 \\
\hline & 8 & 8.5 & 8 & 7.5 & 7.5 & 8.5 & 8 & 56 \\
\hline & 0.143 & 0.152 & 0.143 & 0.134 & 0.134 & 0.152 & 0.143 & 1 \\
\hline \multirow{2}{*}{ 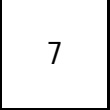 } & 8.5 & 8 & 8 & 7.5 & 8 & 9 & 9 & 58 \\
\hline & 0.147 & 0.138 & 0.138 & 0.129 & 0.138 & 0.155 & 0.155 & 1 \\
\hline & 8 & 7.5 & 8 & 8.5 & 7.5 & 8.5 & 8.5 & 56.5 \\
\hline & 0.142 & 0.133 & 0.142 & 0.150 & 0.133 & 0.150 & 0.150 & 1 \\
\hline & 8 & 8 & 7.5 & 8 & 8.5 & 9 & 8.5 & 57.5 \\
\hline & 0.139 & 0.139 & 0.130 & 0.139 & 0.149 & 0.157 & 0.149 & 1 \\
\hline \multirow{2}{*}{10} & 8 & 8.5 & 8 & 8 & 7.5 & 8.5 & 8.5 & 57 \\
\hline & 0.140 & 0.149 & 0.140 & 0.140 & 0.132 & 0.149 & 0.149 & 1 \\
\hline Mean & 0.141 & 0.141 & 0.140 & 0.140 & 0.138 & 0.150 & 0.149 & \\
\hline
\end{tabular}

\section{DISCUSSION}

The first round findings also indicate that industry expert groups specify two variables, different from TVET expert groups. The variables are authorized body certification (V11) and skill sets (V12). The same view is expressed in Variable 1 to Variable 10 by both industry and TVET expert groups. The variables selected from the second round are V1, V4, V5, V6, V7, V11 and V12.Variables 11 and 12 remain available as choices from expert group. The variable mentioned in the first round was reaffirmed by all experts. Experts have determined which variables are the priority After going through the second round as indicated in Table 3. As a result of this validation, only seven variables are selected.

In the third round, V11 will have the highest points of 85.5 per cent with the average points of 0.150 as shown in Table 5 . V12 is the second highest point of 85 per cent with an average point of 0.149 . Then, V1 and V4 at 80.5 per cent with an average of 0.141 . All variables in Table 5 are above 78 per cent. According to Kanniah \& Mahrin, when the expert agreed that the strategy outlined had an impact on the secure implementation of software development and there was no need for a second round as a consensus was reached within the current round [27].

Table 5: Variable Percentage and Mean

\begin{tabular}{|c|c|l|c|c|}
\hline No. & Indicator & \multicolumn{1}{|c|}{ Variable } & $\begin{array}{c}\text { Percentage } \\
\%\end{array}$ & Mean \\
\hline 1 & V11 & $\begin{array}{l}\text { Authorized Body } \\
\text { Certification }\end{array}$ & 85.5 & 0.150 \\
\hline 2 & V12 & Skill Sets & 85 & 0.149 \\
\hline 3 & V1 & $\begin{array}{l}\text { Quality } \\
\text { Assurance }\end{array}$ & 80.5 & 0.141 \\
\hline 4 & V4 & $\begin{array}{l}\text { High-Quality } \\
\text { Education }\end{array}$ & 80.5 & 0.141 \\
\hline 5 & V6 & $\begin{array}{l}\text { Industrial } \\
\text { Training }\end{array}$ & 80 & 0.140 \\
\hline 6 & V5 & $\begin{array}{l}\text { Evidence-Based } \\
\text { Knowledge }\end{array}$ & 79.5 & 0.140 \\
\hline 7 & V7 & $\begin{array}{l}\text { Industry } \\
\text { Involvement }\end{array}$ & 78.5 & 0.138 \\
\hline
\end{tabular}

\section{CONCLUSION}

This research was conducted to develop the Centre of Accreditation and Recognition of Excellence (CARE) with Industrial based Recognition. From the Delphi process, the strategy to develop Centre of Accreditation and Recognition of Excellence (CARE) with Industrial-based Recognition has been established. The strategy shall included authorized body certification, skill sets, quality assurance, high-quality education, industrial training, evidence-based knowledge and industry involvement. The findings are supported by previous studies as indicated in the review of literature. The results also show two variables identified as different variables and an explorative idea by the expert group. These variables are authorized body certification and skill sets, which may be further elaborated on future research.

\section{Acknowledgements}

This work is supported by Universiti Teknologi Malaysia under Research University Grant Q.K130000.3556.07G32 and Q.K130000.3556.06G05 for the financial support provided throughout the course of this research project.

\section{REFERENCES}

1. M. Z. Ibrahim, M. N. Ab Rahman, and R. M. Yasin. Assessing students perceptions of service quality in technical educational and vocational training (TEVT) 
institution in Malaysia, Procedia-Social and Behavioral Sciences, vol. 56, 2012, pp. 272-283.

2. MQA. Code of Practice for TVET Programme Accreditation (COPTPA) (no. 20 Mac). Malaysian Qualifications Agency, 2019.

3. C. Te-Yung. Problems and strategies for improving the non-formal learning accreditation system in Taiwan, Procedia-Social and Behavioral Sciences, vol. 142, 2014, pp. 578-585.

4. H. Simsek and A. Yildirim. Vocational schools in Turkey: An administrative and organizational analysis, International Review of Education, vol. 46, no. 3-4, pp. 327-342, July 2000.

5. E. Munastiwi. The Management Model of Vocational Education Quality Assurance Using 'Holistic Skills Education (Holsked), Procedia-Social and Behavioral Sciences, vol. 204, pp. 218-230, Aug. 2015.

6. C. Reigeluth. What is Instructional Design Theory and How Is it Changing? (93), vol. 2, 1999, pp. 5-29.

7. V. Aarkrog. Learning in the workplace and the significance of school $\square$ based education: a study of learning in a Danish vocational education and training programme, International journal of lifelong education, vol. 24, no. 2, pp. 137-147, March 2005.

8. L. Moldovan. Design of a new learning environment for training in quality assurance, Procedia Technology, vol. 12, 2014, pp. 483-488.

9. C. Tukundane, A. Minnaert, J. Zeelen, and P. Kanyandago. Building vocational skills for marginalised youth in Uganda: A SWOT analysis of four training programmes, International Journal of Educational Development, vol. 40, pp. 134-144, Jan. 2015.

10. P. C. Diep. Substantial policies and measures to promote quality assurance of TVET in Vietnam towards mutual recognition of qualifications in ASEAN,TVET@Asia, 7, Aug. 2016.

11. I. Buliginaa, B. Slokab, J. Dzelmec, and G. Torad. Quality and transparency in VET: new challenges for public administrations in Latvia, Procedia-Social and Behavioral Sciences, vol. 156, 2014, pp. 355-359.

12. G. V. Mozhaeva, N. Aniskina, G. Serbina, and P. Mozhaeva Renha. Development of vet quality in Russia in the context of the European model of education quality CQAF, 2015.

13. Z. Halili and A. Rukovci. Impact of Accreditation Process on Quality Improvement in Vocational Education and Training Institutions in Kosovo, International Journal on New Trends in Education \& their Implications (IJONTE), vol. 11, no. 1, Jan. 2020.

14. E. Cerkez, D. Stroie, and Z. Vladut. Vocational education and training in Europe-Romania. Cedefop ReferNet VET in Europe reports, 2016.

15. U. Hippach-Schneider and A. Huismann. Vocational education and training in Europe-Germany, in Cedefop ReferNet VET in Europe reports, 2016.
16. P. E. Unit. The system of education in Poland (Warsaw: Foundation for the Development of the Education System (FRSE)). 2012.

17. E. C. f. t. D. o. V. Training. Apprenticeship-type schemes and structured work-based learning programmes, 2014.

18. DGERT. Vocational education and training in Europe-Portugal, in Cedefop ReferNet VET in Europe reports, 2019.

19. Cedefop, Vocational education and training in Bulgaria: short description, 2018.

20. D. EAC. Education and Training Monitor 2015 in Cyprus, ed. Luxembourg: Publications Office of the European Union, 2015.

21. Y. Korelli and Y. Mourouzides. Vocational education and training in Europe-Cyprus. Cedefop ReferNet VET in Europe reports, ed, 2016.

22. J. A. Baser, N. A. M. Jizat, F. A. N. Yunus, M. B. Rahim, A. R. A. Razzaq, and A. Hasan. Competency of National Dual Training System Industry Advisors, Jurnal Pendidikan Teknologi dan Kejuruan, vol. 23, no. 4, pp. 328-338, Oct. 2017.

23. A. Ahmad. Effectiveness of learning transfer in national dual training system (NDTS), Universiti Tun Hussein Onn Malaysia, Oct. 2011.

24. T. Hayes. Delphi study of the future of marketing of higher education, Journal of Business Research, vol. 60, no. 9, pp. 927 - 931, Dec. 2006. https://doi.org/10.1016/j.jbusres.2006.12.009

25. C. Hsu and B. A. Sandford. The Delphi technique: making sense of consensus, Practical Assessment, Research, and Evaluation, vol. 12, no. 1, pp. 10, Aug. 2007.

26. C. Okoli and S. D. Pawlowski. The Delphi method as a research tool: an example, design considerations and applications, Information \& Management, vol. 42, no. 1, pp. 15-29, Dec. 2004.

27. S. L. Kanniah and M. N. r. Mahrin. Secure software development practice adoption model: A delphi study, Journal of Telecommunication, Electronic and Computer Engineering (JTEC), vol. 10, no. 2-8, pp. 71-75, July 2018. 